\title{
Using Integrative Approach in Science Teaching And Its Effect On The Students' Attitude Toward Learning Science
}

\author{
Eman wefky Abodahab \\ Sohage University, Egypt
}

\begin{abstract}
attitudes toward learning science in primary school level. sample of this study was 29 students in8th grade at Naser prep Girls' School in Egypt. The data were analysed according to the following question: what are the effects of using STEM Education approach in teaching science on students' attitude toward learning science in primary school? The data were collected by using an attitude scale. The data analysis indicates that there were significant differences between the students' responses in the pre-test and the post-test in the attitude scale in favor of the post-test.
\end{abstract}

Keywords: STEM Education; Attitude; Attitude Scale. 